which there are many illustrious examples still living, the second condition was strictly applicable."

\section{The Interior of the Earth}

At a meeting of the Royal Society held on January 17, 1839, W. Hopkins read his second paper on the state of the interior of the earth, entitled "The Phenomena of Precession and Nutation, assuming the Fluidity of the Interior of the Earth". For the purpose of his investigation Hopkins assumed the solid shell of the earth to be bounded by a determinate inner spheroidal surface of which the ellipticity is equal to that of the outer surface and the shell and fluid to be homogeneous and of equal density. Having given the results of his inquiries as affecting precession, and lunar and solar rotation he said that "the pole of the earth would have a small eircular motion, depending entirely on the internal fluidity. The radius of the circle thus described would be greatest when the thickness of the shell should be least; but the inequality thus produced would not, for the smallest thickness of the shell, exceed a quantity of the same order as the polar nutation, and for any but the most inconsiderable thickness of the shell, would be entirely inappreciable to observation."

\section{English Medical Society in Paris}

THE Lancet of January 20, 1839, contains the following information: "An English medical society has recently been established in Paris and already includes on its list between 90 and 100 members. At one of the last meetings Sir R. Chermside was elected president and J. Godfrey, Esq., vice-president for the present year. The Society holds weekly meetings at which papers are read upon medical subjects and discussions take place in the English language. These meetings are peculiarly interesting, as medical men from London, Edinburgh, Dublin and different parts of America join in the proceedings, as well as some of the 'externes' and 'internes' of the Parisian hospitals. The Society has established a reading room for the English and French periodicals, and the nucleus of a permanent library is already in existence."

\section{Geodetical Work at the Cape of Good Hope}

IN his "Autobiography", under the year 1839, Airy wrote, "I had much work in connection with the Cape of Good Hope Observatory, chiefly relating to instrumental equipment and to the geodetical work. As it was considered advisable that any base measured in the Cape Colony should be measured with compensation bars, I applied to Major Jervis for the loan of those belonging to the East Indian Survey, but he positively refused to lend them. On Jan. 20th I applied to Col. Colby for the compensation bars of the British Survey, and he immediately assented to lending them. Col. Colby had suggested to the Ordnance Department that Capt. Henderson and several sappers should be sent to use the measuring bars and it was so arranged. It still appeared desirable to have the command of some soldier's from the Garrison of Cape 'Town, and this matter was soon arranged with the Military authorities by the Admiralty."

The geodetical work at the Cape included the remeasurement and extension of Lacaille's arc, and it was carried out by Sir Thomas Maclear, the Astronomer Royal at the Cape, the results being published in 1866, edited by Airy.

\section{Societies and Academies}

\section{London}

Royal Society (Proc. A, 169, 149-289; 1938).

C. K. Ingold : Structure of benzene (Bakerian Lecture).

W. F. Hilton : Photography of airscrew sound waves.

D. H. Everett and W. F. K. WYNnE-Jones: Dissociation of the ammonium ion and the basic strength of ammonia in water.

H. S. W. Massey and R. A. Buckingham: Low temperature properties of gaseous helium.

J. N. AGAR and F. P. BowDEN : Kinetics of electrode reactions ( 1 and 2 ).

R. G. Arckin, N. S. Bayliss and A. L. G. Rees : Effect of solvents on the continuous absorption spectrum of bromine.

T. E. Altibone and J. M. Meek : Development of the spark discharge (2).

S. C. Curran, P. I. Dee and V. Petržílika : Excitation of $\gamma$-radiation in processes of proton capture by light elements.

\section{Paris}

Academy of Sciences (C.R., 207, 1137-1268, Dec. 12, 1938).*

H. BRUCK : Extension of the $1^{1} P_{1}-m^{1} S_{0}$ of zine.

M. PARODI : Spectra of some derivatives of methane in the far infra-red.

L. Montraur : Absorption and fluorescence spectra of pigments from the St. John's wort of the Mediter. ranean basin (Hypericum crispum). The Hypericum from Tunis, which often poisons animals, has different pigments from the European Hypericum.

J. Debresse : Absorption spectra and chemical constitution of Sauton's liquid cultivated in tubercle bacilli B.C.G.

G. Emschwiller : Production of iodic anhydride by photo-oxidation of organic oxides; photooxidation of iodoform and of solid carbon tetraiodide.

H. Hulubei, Mlle. Y. Cauchois and Mme. S. Cotelle : Spectroscopic determination of the atomic number of polonium. The investigation shows that the detection of elements by their X-ray spectra is much more sensitive than was believed; the radia. tions detected in this case are those to be expected from an element of atomic number 84.

A. Cladde : Fluorescent tube-lamps functioning with the usual distribution voltage.

M. BRutzcus : A thermochemical constant and its relations with electronic energy values.

R. EngELAND: A new form of stereo-isomerism and an unknown form of glycocoll : attempt at a theoretical interpretation.

V. AUGer : Two new molybdic acids.

R. Chauvenet : Combinations of zinc nitrate and of alkaline nitrates.

A. Moretre : The system iodine-vanadium : vanadium di-iode and tri-iodide.

G. CountoIs : Preparation of anhydrous sodium sulphide.

C. Dufraisse and M. German : Study of the mechanism of dry extinction by dusts; nitrate, chlorate, perchlorate of potassium and other bodies which support combustion as extinguishers of flames. *Continued from page 39. 
P. Grammaticakis: Action of organomagnesium mixtures on the benzylimines : preparation of secondary amines of the type Ar.(R)CH.NH. $\mathrm{CH}_{2} \cdot \mathrm{C}_{6} \mathrm{H}_{5}$.

D. DUVEen and A. WILlEmarT: Synthesis of tetraphenyl - 2.6.10.12 bis-(diphenyl)-9. I1-naphthacene and its photo-oxide.

M. TUот : Interpretation of secondary reactions observed in the course of the condensation by organomagnesium of ketones and of esters of the aliphatic series : theory.

Mme. R. Dubertret, L. Doncieux, H. Vautrin and L. DUBERTRET : The nummulitic of the eastern slope of the Anti-Libanon (region of Damascus, Syria).

Mme. A. VASsy and E. VASSY : Daily variations of the mean temperature of the atmospheric ozone.

G. Lemee : Post-glacial forest history in Lower Normandy after pollen analysis of the peat-bogs.

J. MotTe : Evolution of the nuclei of the internodal cells of Chara foetida.

Mme. I. MichatsKa and F.-X. Skupienski : Ecological researches on Polysphondylium pallidum Olive, Polysphondylium violaceum Bref., Dictyostelium mucoroides Bref.

Mule. J. MANuel : Formation of the ascus of Nematospora Coryli, after a sexual phenomenon.

P. Riou and G. Delorme : Distribution of manganese and of iron in the ashes and elms of the Province of Quebec.

R. UlRICH: Variations of the reactions to superficial lesions as a function of their surface (fruits of Iris pallida Lam.).

V. VINCENT and P. Boischot : Nature and composition of the organic matter of the phosphates of North Africa: the phosphate of Gafsa.

J. Georgevitch : Spharactinomyxon danico n.sp., an actinomyxidian parasitic on an oligochæte of Lake Ochrida.

RAYMOND-HAMET: Major hypotensor and sympathetolitic effects of hydrocinchonidine.

MLIE. P. Berthrer : Coefficient of magnetization and electric sign of solutions of hæmatin and of acethæmin.

B. Luyet and G. Thoennes : Revival of muscle fibres vitrified in liquid air.

M. Rangier and P. DE Traverse: Mode of formation and constitution of urinary scatole red.

G. RAMON : Some methods for the rapid and intensive production of diphtheria and tetanus antitoxins in the horse.

A. Sartory, J. Meyer and D. Schmutz: Conditions favouring bacterial growth by preliminary introduction of vitamins $B_{1}$ and $B_{2}$ combined and in varied doses, into the culture medium.

J. RÉgnier and Mute. S. Lambin : Study of microbial growth as a function of the quantity of nutritive substance in culture media.

J. Chaussin and L. Lesceur : Study of the variations of phthalein and formol acidities of urine during 24 hours of eight diabeties.

\section{Sydney}

Royal Society of New South Wales ( $J$. and Proc., 72 ; 1937-38).

S. B. Cohen and F. M. Quodling: An X-ray examination of chillagite. From oscillation and powder photographs (copper $K \alpha$ ) chillagite has been found to have cell dimensions in close agreement with those of wulfenite and stolzite and the same number of molecules per cell (4). Chillagite is regarded as a mixed crystal of these two substances, not as a distinct mineral species.

J. G. Churchward : Studies on physiological specialization of the organisms causing bunt in wheat, and the genetics of resistance to this and certain other wheat diseases. (2) Genetical studies. In a wheat cross, Federation $\times$ Hope, studies were made in the field and greenhouse on the inheritance of resistance to bunt, to flagsmut, to two races of stem rust, and certain morphological characters. In addition to the single factor for resistance to bunt, there are several modifying factors acting in this cross. With two exceptions, the inheritance of the remaining characters is explained by simple Mendelian hypotheses.

S. W. CAREY and W. R. Browne : Review of the carboniferous stratigraphy, tectonics and palæogeography of New South Wales and Queensland. A scheme of subdivision is proposed for the Lower and Middle Carboniferous of New South Wales, embodying recognition of the fact that freshwater and marine sedimentation proceeded simultaneously in Visean time. Many, if not all, the known occurrences fit into this scheme. Correlations are also instituted with Queensland. The earth-movements which determined loci of sedimentation and affected the sediments after deposition are enumerated--the late Devonian Kanimbla, the epi-Burindi Drummond and the late Permian Hunter-Bowen orogenies, with minor vertical movements at the close of Lower Burindi and Upper Kuttung times.

Adolph Bolliger and A. L. Carrodus : Changes in and around the pouch in Trichosurus vulpecula, as occurring naturally and as the result of the administration of œstrone. The sexually immature Australian opossum (Trichosurus vulpecula) shows no pigmentation in its undeveloped pouch, and the hair on its ventral aspect is usually white. Injections of œstrone bring on development of the pouch, mammary glands become evident, and the nipples undergo hypertrophy. Simultaneously a pigment is secreted within the pouch and forms a dark brown deposit, while the hairs within the pouch as well as those around it become stained from a yellow to a dark golden brown. Similar changes were observed to occur under natural conditions, and they are considered to be connected with the sex life of the animal.

\section{Washington, D.C.}

\section{National Academy of Sciences (Proc., 24, 497-523,} Nov. 15, 1938).

R. A. Brink and D. C. Cooper : Partial selfincompatibility in Medicago sativa. Pollen is less efficient in self-pollinations than in cross-pollinations, while ovules containing inbred embryos show a greater tendency to collapse than those from crossfertilization.

J. G. Carlson : Mitotic behaviour of induced chromosomal fragments lacking spindle attachments in the neuroblasts of the grasshopper.

C. Stock: A titanothere from the type Sespe of California.

Barbara S. Burks : Autosomal linkage in man : the recombination ratio between congenital tooth deficiency and hair colour.

R. Courant : Remarks on Plateau's and Douglas's problem. 